https://doi.org/10.30910/turkjans.595190

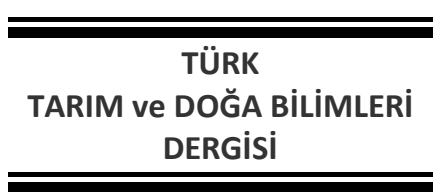

TÜRK

DERGISI

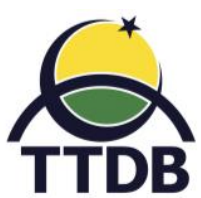

www.dergipark.gov.tr/turkjans

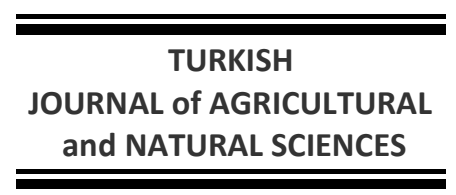

Araştırma Makalesi

\title{
Bazı Çeltik Çeşitlerinin Besleme Değerinin Tespiti
}

\author{
Tugay AYAŞAN ${ }^{1 *}$, İsmail ÜLGER ${ }^{2}$, Bülent ÖZSOY ${ }^{3}$ \\ ${ }^{1}$ Doğu Akdeniz Tarımsal Araştırma Enstitüsü Müdürlüğü, Adana-Türkiye \\ ${ }^{2}$ Erciyes Üniversitesi Seyrani Ziraat Fakültesi Zootekni Bölümü, Kayseri-Türkiye \\ ${ }^{3}$ Aydın Adnan Menderes Üniversitesi Veteriner Fakültesi Hayvan Besleme ve Beslenme Hastalıkları Anabilim Dalı, \\ Efeler, Aydın-Türkiye
}

*Sorumlu yazar: tayasan@gmail.com

Geliş Tarihi: 08.02.2019

Düzeltme Geliş Tarihi: 20.05.2019

Kabul Tarihi: 26.06.2019

Özet

$\mathrm{Bu}$ çalışma, 5 farklı çeltik çeşidine (Efe, Yatkın, Halilbey, Kızıltan, Osmancık-97) ait tohumların besin değerlerinin tespit edilmesi amacıyla gerçekleştirilmiştir. Araştırma 2018 yılında yürütülmüştür. Araştırma sonucunda, çeltik çeşitleri arasında, kuru madde (KM), ham protein (HP) ve ham yağ (HY) içerikleri istatistiki anlamda önemli düzeyde $(P<0.05)$ farklılıklar tespit edilirken; ham kül $(H K)$ içerikleri bakımından istatistiki anlamda bir farklılık bulunmamıştır. Çeltik çeşitleri arasında asit deterjanda çözünmeyen lif (ADF), nötr deterjanda çözünmeyen lif (NDF), ham selüloz (HS) ve fiber olmayan karbonhidrat (FOK) içeriklerinin ayrıca toplam sindirilebilir besin maddesi (TSBM), sindirilebilir enerji (SE), metabolik enerji (ME) ve net enerji laktasyon (NEL) değerlerinin istatistiki anlamda önemli olmadığı tespit edilmiştir. Çeltik çeşitleri arasında en yüksek HP \%7.56 ile Halilbey ve \%7.24 ile Kızıltan çeşidinde tespit edilmiştir. Çeltik çeşitlerinin HY oranları \%1.90-2.07 arasında değişim göstermiştir.

Anahtar kelimeler: Çeltik çeşitleri, kimyasal kompozisyon, sindirilebilirlik, enerji.

\section{Determination of Feeding Value of Some Rice Varieties}

\begin{abstract}
This study was carried out in order to evaluate the nutritional value of 5 different rice varieties (Efe, Yatkın, Halilbey, Kızıltan, Osmancık-97). The research was carried out in 2018. As a result of the study, the differences in dry matter (DM), crude fat (CF) and crude protein (CP) contents among the rice cultivars were statistically significant (P $<0.05$ ) but crude ash (CA) contents differences were found statistically non-significant. The content of acid detergent insoluble fiber (ADF), neutral detergent insoluble fiber (NDF), crude cellulose (CC) and non-fiber carbohydrates (NFC) also the differences in total digestible nutrients (TDN), digestible energy (DE), metabolic energy (ME) and net energy lactation (NEL) values are not statistically significant among paddy varieties. Among the rice varieties, the highest HP was determined with $7.56 \%$ Halilbey and $7.24 \%$ with Kızıltan cultivars. Crude fat rates of paddy cultivars ranged from $1.90 \%$ to $2.07 \%$.
\end{abstract}

Key words: Rice varieties, chemical composition, digestibility, energy.

\section{Giriş}

Ham maddesi çeltik olan pirinç, besin kaynağı olarak kullanılan en önemli ürünlerden bir tanesidir. Pilav ve çoğu yemekte kullanılan pirinç, ülkemizin çoğu yerinde özellikle Marmara ve Karadeniz Bölgesi'nde çeltik olarak yetiştirilmektedir (Anonim, 2016). 
Ülkemizde 2010 yılı çeltik ekiliş alanı 99.000 ha; çeltik üretimi 860.000 ton, çeltik tüketimi 527.000 ton, verim de $869 \mathrm{~kg} /$ da iken; bu 2015 yılında sırasıyla 99.400 ha, 820.000 ton, 754.000 ton ve $906 \mathrm{~kg} / \mathrm{da}$ olarak gerçekleşmiştir. 2017 yılında 900 bin ton olan çeltik üretiminin 2018 yılında \%4.4 artışla 940 bin ton olarak gerçekleşeceği tahmin edilmektedir (TUiK, 2017). Dünya genelindeki nüfus artış hızının devamlı artış göstermesi ile beraber, 2030 yılındaki talebi karşılamak için çeltik üretiminin ülkemizde yaklaşık $\% 50$ oranında artırılması gerektiği tahmin edilmektedir.

Ülkemizde çeltik ile ilgili çalışmalar gerek üniversitelerde gerekse araştırma enstitülerinde yapılmaya başlanmıştır (Sezer, 1993). Bu araştırmaya bahis olan Efe, Yatkın, Halilbey, Kızıltan ve Osmancık97 çeşitleri Trakya Tarımsal Araştırma Enstitüsü Müdürlüğü'nde yetiştirilmekte olan çeltik çeşitleridir. Çalışmada kullanılan çeltik çeşitlerinden birisi olan Osmancık-97; 1997 yılında Trakya Tarımsal Araştırma Enstitüsü tarafından tescil ettirilen bir çeşittir. Farklı ekolojilere uyum sağlamada üstündür. Halilbey, 2004 yılında tescil ettirilen, olgunlaşma süresi 130-135 gün olan bir çeşittir. Kızıltan, 2007 yılında tescil edilen, 130-135 günde olgunlaşan bir çeşittir. Efe çeşidi, 2011 yılında Trakya Tarımsal Araştırma Enstitüsü tarafından tescil ettirilen bir çeşit olup; olgunlaşma süresi 120130 gün olan ve yüksek verim potansiyeline sahip bir çeşittir. Yatkın çeşidi ise 2013 yılında tescil edilen, 130135 gün arasında olgunlaşan bir çeşittir (Trakya Tarımsal Araştırma Enstitüsü Müdürlüğü, 2018).

Yemlerin besin değerinin belirlenmesi için kullanılan birçok yöntem vardır. Çalışma, Trakya Tarımsal Araştırma Enstitüsünden temin edilen farklı çeltik çeşitlerine (Efe, Yatkın, Halilbey, Kızıltan ve Osmancık-97) ait tohumların besin değerlerinin tespit edilmesi amacıyla gerçekleştirilmiştir.

\section{Materyal ve Yöntem Yem materyali}

Araştırmanın yem materyalini Trakya Tarımsal Araştırma Enstitüsünden temin edilen farklı çeltik çeşitleri (Efe, Yatkın, Halilbey, Kızıltan ve Osmancık97) oluşturmuştur. Çeltik, toprak yönünden seçici olmayıp, her türlü toprak koşullarında yetiştirilebilir. Çeltik, tuzlu topraklara uyum sağlamaktadır. Çeltiğin çimlenmesi için $18-40^{\circ} \mathrm{C}$ sıcaklık gerekmektedir. Araştırma 2018 yılında gerçekleştirilmiştir.

\section{Kimyasal analizler}

5 farklı çeltik çeşidine ait örnekler, Erciyes Üniversitesi Ziraat Fakültesi Zootekni Bölümü'nde bulunan yem laboratuvarına gönderilerek orada besin madde analizleri yapılmıştır.

Kuru yem örnekleri $1 \mathrm{~mm}$ elek çapına sahip değirmende öğütülerek analizlerde kullanılmıştır. Kuru madde (KM) içeriğinin saptanması amacıyla, öğütülmüş örnekler 24 saat süreyle $70{ }^{\circ} \mathrm{C}$ sıcaklıktaki etüvde bekletilerek, fırınlama öncesi ve sonrası tartımlar arasındaki farklılıklar yüzde cinsinden KM olarak ifade edilmiştir. Ham kül (HK) içeriği örneklerin $550{ }^{\circ} \mathrm{C}^{\prime}$ de 4 saat kül fırınında yakılmasıyla tespit edilmiştir. Azot (N) içeriğinin saptanmasında Kjeldahl metodundan yararlanılmıştır. Ham protein (HP) içeriği ise "\% HP=N × 6.25" formülü ile hesaplanmıştır (AOAC, 1990). Ham yağ (HY) analizi AOAC (1990) tarafından önerilen yönteme göre SER148 Soxhlet (Velp Scientifica, Milano, İtalya) cihazı ile yapılmıştır.

NDF (Nötr deterjan lif) ve ADF (Asit deterjan lif) içerikleri ANKOM 200 fiber analizör (ANKOM Teknoloji, NY, ABD) ile saptanmıştır (Van Soest ve ark. (1991). Ham selüloz (HS) değerlerinin hesaplanmasında, Pinkerton (2005) tarafından bildirilen "\% $\mathrm{HS}=0.80$ x \% ADF" eşitliğinden yararlanılmıştır.

Fiber olmayan karbonhidrat (FOK) içeriği ise, Weiss ve ark. (1992) tarafından bildirilen "\% FOK=100(\% NDF + \% HP + \% HY + \% HK)" eşitliği ile hesaplanmıştır. Toplam sindirilebilir besin maddesi (TSBM), sindirilebilir enerji (SE), metabolik enerji (ME) ve net enerji laktasyon (NEL) değerleri MAFF (1984) tarafından bildirilen ve aşağıda gösterilen eşitlikler ile hesaplanmıştır:

$$
\begin{gathered}
\text { TSBM }(\%)=27.66 \times \text { ME }(\text { Mcal } / \text { kg KM }) \\
\text { SE }(\text { Mcal } / \text { kg KM })=0.04409 \times \text { TSBM }(\%) \\
\text { ME }(\text { Mcal/kg KM })=[3227-\{35.85 \times \text { ADF }(\%)+ \\
33.46 \times \text { HP }(\%)-35.85 \times \text { HK }(\%)\} / 1000] \\
\text { NEL }(\text { Mcal } / \text { kg KM })=\{0.0245 \times \text { TSBM }(\%)\}-0.12
\end{gathered}
$$

\section{istatistiksel analizler}

İstatistiksel analizler, SPSS (1999) paket programı kullanılarak yapılmıştır. Araştırmadan elde edilen verilerin varyans analizi (One-way ANOVA) ile incelenen özellikler bakımından çeşitlere ait ortalamalar arasındaki farklılıklar tespit edilmiştir. Görülen farklılıkların önem seviyelerinin tespitinde ise Duncan çoklu karşılaştırma testinden faydalanılmıştır.

\section{Bulgular ve Tartışma}

Araştırma materyali çeltik çeşitlerine ait KM, HK, HP ve HY içerikleri Çizelge $1^{\prime}$ 'de gösterilmiştir. 
Çizelge 1. Çeltik çeşitlerine ait KM, HK, HP ve HY düzeyleri

\begin{tabular}{lcccc}
\hline Çeşitler & KM, (\%) & HK, (\%) & HP, (\%) & HY, (\%) \\
\hline Efe & $87.99^{\mathrm{c}}$ & 5.22 & $5.81^{\mathrm{c}}$ & $1.90^{\mathrm{a}}$ \\
Yatkın & $87.38^{\mathrm{d}}$ & 5.54 & $6.09^{\mathrm{c}}$ & $1.90^{\mathrm{a}}$ \\
Halilbey & $86.54^{\mathrm{e}}$ & 5.45 & $7.56^{\mathrm{a}}$ & $1.60^{\mathrm{b}}$ \\
Kızıltan & $88.43^{\mathrm{b}}$ & 5.60 & $7.24^{\mathrm{ab}}$ & $2.07^{\mathrm{a}}$ \\
Osmancık-97 & $88.65^{\mathrm{a}}$ & 5.54 & $6.59^{\mathrm{bc}}$ & $1.96^{\mathrm{a}}$ \\
\hline O.S.H. & 0,255 & 0.062 & 0.236 & 0.055 \\
P & $<0.001$ & 0.139 & 0.018 & 0.009 \\
\hline
\end{tabular}

OSH: Ortalamalara ait standart hata; P: Olasılık değeri.

Çizelge 1'den görülebileceği gibi, çeşitler arasında KM $(P<0.01)$, HP $(P<0.05)$ ve HY $(P<0.01)$ içerikleri bakımından görülen farklılıklar istatistiki anlamda önemli düzeyde iken; HK içerikleri bakımından istatistiki anlamda önemli farklılıklar oluşmamıştır.

Araştırma materyali çeltik çeşitlerine ait ADF, NDF, ham selüloz ve fiber olmayan karbonhidrat içerikleri Çizelge 2'de gösterilmiştir.

Çizelge 2. Çeltik çeşitlerine ait ADF, NDF, HS ve FOK düzeyleri

\begin{tabular}{lcccc}
\hline Çeşitler & ADF, (\%) & NDF, (\%) & HS, (\%) & FOK, (\%) \\
\hline Efe & $14.08^{*}$ & 17.19 & 11.26 & 69.89 \\
Yatkın & 14.60 & 18.29 & 11.68 & 68.50 \\
Halilbey & 16.29 & 18.20 & 13.03 & 67.19 \\
Kızıltan & 16.94 & 19.74 & 13.55 & 65.35 \\
Osmancık-97 & 15.55 & 18.88 & 12.44 & 67.04 \\
\hline O.S.H. & 0.414 & 0.467 & 0.331 & 0.626 \\
P & 0.121 & 0.623 & 0.122 & 0.184 \\
\hline
\end{tabular}

OSH: Ortalamalara ait standart hata; P: Olasılık değeri. ${ }^{*} \mathrm{P}>0.05$.

Çizelge 2'den görüleceği üzere, çeşitler arasında ADF, NDF, HS ve FOK içerikleri bakımından görülen farklılıkların istatistiki anlamda önemli olmadığı tespit edilmiştir $(P>0.05)$. Araştırma materyali çeltik çeşitlerine ait toplam sindirilebilir besin maddesi, sindirilebilir enerji, metabolik enerji ve net enerji laktasyon içerikleri Çizelge 3'de gösterilmiştir.

Çizelge 3. Çeltik çeşitlerine ait TSBM, SE, ME ve NEL düzeyleri

\begin{tabular}{lcccc}
\hline Çeşitler & TSBM, (\%) & SE, (Mcal/Kg) & ME, (Mcal/Kg) & NEL, (Mcal/Kg) \\
\hline Efe & $75.51^{*}$ & 3.33 & 2.73 & 1.73 \\
Yatkın & 75.22 & 3.32 & 2.72 & 1.72 \\
Halilbey & 74.71 & 3.30 & 2.70 & 1.71 \\
Kızıltan & 73.61 & 3.25 & 2.66 & 1.69 \\
Osmancık-97 & 74.45 & 3.29 & 2.69 & 1.70 \\
\hline O.S.H. & 0.266 & 0.012 & 0.010 & 0.006 \\
P & 0.146 & 0.146 & 0.122 & 0.136 \\
\hline
\end{tabular}

$* P>0.05$.

Çeşitler arasında TSBM, SE, ME ve NEL değerleri bakımından istatistiki anlamda bir farklılık bulunmamıştır.

Sözkonusu çeltik çeşitlerinin kuru madde (KM) içeriği ortalama \%87.80 olarak bulunmuştur. Çizelge 1'e bakıldığında KM değerlerinin \%86.54 ile \%88.65 arasında değiştiği görülmüştür $(P<0.05)$. Çavdar
(2014), çeltiğin KM oranının \%87 olduğunu ifade ederken; yapılan bir başka çalışmada çeltik çeşitlerinin KM içeriklerinin çeşitlere göre farklılık arz ettiği ve KM içeriklerinin \%88.19-88.95 arasında değişim gösterdiği saptanmıştır (Sahu ve ark. 2018). KM içeriklerinin literatürde farklılık göstermesi, çeşit, lokasyon, 
depolama, farklı azot dozları, yetiştirme, vb. faktörlere bağııdır.

Çeltik çeşitlerinin ortalama ham protein (HP) değeri \%6.66 olarak saptanmış olup; en yüksek HP değeri \%7.56 ile Halilbey çeşidi ve \%7.24 ile Kızıltan çeşidinden elde edilmiştir. Toksal (1991), HP oranını bazı çeltik çeşitlerinde \%6.93-8.97 arasında bulurken, Gevrek (2000), çeltik danesindeki HP oranının yıllara göre değişmekle beraber \%9.99 olduğunu ifade etmiştir. Ahmad ve ark. (2013), HP oranını \%6.19-6.30; Donduran (2014), \%5.64-8.86; Hakoomat ve ark. (2014)'da \%9.68-10.31 arasında bulmuştur. Denemede çeltik çeşitlerinde belirlenen ortalama HP değeri (\%6.66), Hakoomat ve ark. (2014)'in saptadığı \%9.68-10.31 değerlerinden düşük bulunmuştur. Naik ve Chetti (2017), çeltiğin HP içeriğini \%7.15-7.53 arasında tespit ederken; Yılmaz ve Sonkaya (2018), çinko uygulamasının farklı çeltik çeşitlerindeki protein oranı üzerine etkisini inceledikleri çalışmada, Efe çeşidinin protein oranını \%11.23; Osmancık-97 çeşidinin protein oranını da \%9.74 olarak bulmuştur. Ham protein içeriğinin farklılık göstermesi çeşitlerin genetik özelliklerinden kaynaklanmış olabileceği gibi, materyalin kavuzlu/kavuzsuz olup olmama durumu vb. durumlardan da kaynaklanabilir.

Serpme ve fideleme ekim yöntemlerinin uygulandığı çeltik çeşitlerinde HP oranına bakan Şavşatlı ve Gülümser (2006), serpme ekim yöntemlerinin uygulandığı çeltik çeşitlerinde HP oranını ortalama \%7.68 olarak tespit ederken; fideleme yönteminde bu değeri \%7.91 olarak saptamıştır. Fideleme yönteminde HP oranının artmasının sebebi, bitkilerin topraktaki besin maddelerinden ve güneş ışığından en iyi şekilde yararlanması olabilir.

Çalışmada ham yağ (HY) oranı, çeltik çeşitleri arasında farklılık yaratmış olup; Halilbey çeşidi \%1.60 ile en düşük HY oranına sahip çeşit; Kızıltan çeşidi de \%2.07 ile HY oranı en yüksek çeşit olmuştur. Baydar (2004), çeltiğin yağ oranının \%0.5 olduğunu ifade ederken; Çavdar (2014), bu oranı \%2.0 olarak tespit etmiştir. Baydar (2004), tahıllar içerisinde karbonhidrat içeriği bakımından yulafın en fakir (\%66), çeltiğin en zengin (\%80) olduğunu, protein içeriği bakımından çeltiğin en fakir (\%7), yulafın da en zengin (\%13.3) ve yağ içeriği bakımından da yulafın en zengin (\%8), çeltiğin de en fakir (\%0.5) olduğunu bildirmiştir.

Paketleme ve depolama koşullarının çeltiğin besin maddelerine olan etkisini araştıran Naik ve Chetti (2017), çeltiğin HP, HY, kül ve karbonhidrat içeriğinin, depolama periyodu arttıkça, azalma gösterdiğini ifade etmiştir. Aynı araştırıcılar deneme başında (0. Ay), uygun çevre sıcaklığında çeltiğin yağ içeriğinin \%2.24 olduğunu; 18 . aydaki düzeyin ise \%1.69 olduğunu bildirmiştir. Sahu ve ark. (2018)'de Madhuraj, Hanthipanjra ve Mahamaya çeşitlerinin yağ oranının \%4.22-4.34; \%3.15-3.21 ve \%3.04-3.38 arasında değişim gösterdiğini tespit etmiştir.

Çeltik çeşitlerinin HK oranı, \%5.22-5.60 arasında değişim göstermiştir ( $P>0.05)$. Çavdar (2014), çeltiğin kül oranının \%1.2 olduğunu ifade etmiştir.

Naik ve Chetti (2017), çeltiğin depolanması ve paketlenmesinin, çeltiğin kül içeriği üzerinde etkin bir rol oynadığını, vakumla paketlemenin, çeltiğin depolanmasında en etkin yol olduğu; uygun çevre sıcaklığındaki depolamada, çeltiğin kül içeriğinin \%0.89-1.51 olduğu; soğuk çevre koşullarındaki depolamada ise \%0.95-1.50 arasında değerler aldığını ifade etmiştir. Depolama ve paketleme, çeltiğin kül içeriğini azaltmıştır. Sahu ve ark. (2018)'da kül içeriğini \%1.00-1.54 arasında, ortalama \%1.23 olarak bulmuşlardır. Toprak yapısı, gübreleme ile sulama, biçim zamanı ve vejetasyon, hasat zamanı, iklim, kurutma ve depolama şartlarındaki farklılıklar gibi bazı faktörler de HK içeriklerini etkileyebilmektedir.

5 farklı çeltik çeşidinin ADF içeriği \%14.08 ile \%16.94 arasında değişim göstermiş ( $P>0.05$ ); NDF içerikleri de \%17.19 ile \%19.74 arasında bulunmuştur.

Çeltik çeşitlerine ait HS değerleri \%11.26-13.55 arasında değişim göstermiştir ( $P>0.05)$. Yapılan bir çalışmada çeltiğin HS oranının \%4 olduğu ifade edilmiştir (Çavdar, 2014). Sahu ve ark. (2018), Madhuraj, Hanthipanjra ve Mahamaya çeşitlerinin selüloz içeriğinin sırasıyla \%2.36-4.25; \%1.62-4.28 ve \%2.24-4.21 olduğunu, ortalama selüloz içeriğinin ise \%3.06 olduğunu tespit etmiştir. Rakamlar arasındaki farklılıklar HS'yi tespit etmek için kullanılan yöntemlerin farklı olmasından kaynaklanmış olabilir.

Çeltik çeşitlerine ait FOK içeriği Efe çeşidinde en yüksek bulunurken (\%69.89); Kızıltan çeşidinde en düşük değeri (\%65.35) almıştır.

Toplam sindirilebilir besin maddesi, bir çeşit sindirilebilir enerji ölçütü olup; farklı denklemlerle bulunmaktadır. Çalışmada farklı çeltik çeşitlerinin TSBM'si \%73.61-75.51, ortalama \%74.70 olarak bulunmuştur.

Sindirilebilir enerji, TSBM'nin bir katsayısı ile çarpılması sonucu elde edilen ve yemle alınan besin maddelerinin sindirilen kısımlarından elde edilen enerjidir. Sindirilebilir enerji, çalışmada, farklı çeltik çeşitleri arasında farklılık göstermemiştir. Metabolik enerji, çeltik çeşitleri arasında 2.66-2.73 Mcal/kg KM değerlerini almıştır. En yüksek ME değeri Efe çeşidinde rastlanılmıştır. Net enerji laktasyon ise çeşitler arasında farklılık göstermemiş, 1.69-1.73 Mcal/kg KM arasında değerler almıştır. 


\section{Sonuç ve Öneriler}

Çalışmada ele alınan çeltik çeşitleri arasında $\mathrm{KM}, \mathrm{HY}$ ve HP istatistiki olarak önemli düzeyde bulunmuştur. Çeltik çeşitlerinin seçimi önemli bir konu olup, çalışmada HP bakımından Halilbey ve Kızııtan çeltik çeşitlerinin en yüksek değerleri aldığı görülmüştür. Halilbey çeşidi, en düşük $H Y^{\prime} y a$ sahip çeşit iken; Efe çeşidi en düşük HK'ya sahip çeşit olmuştur.

\section{Teşekkür}

Çeltik çeşitlerinin teminini sağlayan Trakya Tarımsal Araştırma Enstitüsüne teşekkür ederiz. Bu çalışma, ICAFOF'2018'de sadece özet olarak yayınlanmıştır.

\section{Kaynaklar}

Ahmad, A., Afzal, M., Ahmad, A.U.H., Tahir, M. 2013. Effect of foliar application of silicon on yield and quality of rice (Oryza Sativa L.). Cercetari Agronomice in Moldova, 3(155): 21-28.

Anonim, 2016. Çeltik Yetiştiriciliği (http://bzob.com.tr).

Association of Official Analytical Chemists (AOAC), 1990. Official Method of Analysis. 15th. ed. Washington, DC. USA.

Baydar, H. 2004. Tarla Bitkileri. Isparta Uygulamalı Bilimler Üniversitesi Tarım Bilimleri ve Teknolojileri Fakültesi Tarla Bitkileri Bölümü, Isparta.

Çavdar, K. 2014. Tosya İlçesinde Çeltik Tarımı, Sorunları ve Çözüm Yolları. Gaziosmanpaşa Üniversitesi Ziraat Fakültesi Tarla Bitkileri Bölümü, Lisans Bitirme Tezi, $52 \mathrm{~s}$.

Donduran, D.Ö. 2014. Ülkemizde İşlenen Bazı Çeltik Çeşitlerinin Kalite ve Biyoaktif Özelliklerinin Incelenmesi. Yüksek Lisans Tezi, Çanakkale On Sekiz Mart Üniversitesi, Fen Bilimleri Enstitüsü, Gıda Mühendisliği Anabilim Dalı, Çanakkale.

Gevrek, MH. 2000. Çeltik tarımında azot kaynağı olarak Azola'nın kullanımı üzerine bir araştırma. Turk J. Agric. Forest., 24(2000): 165172.

Hakoomat, A., Hasnain, Z., Sahanzad, A.N., Sarwar, N., Qureshi M.K., Khaliq, S., Qayyum, M.F. 2014. Nitrogen and zinc interaction improves yield and quality of submerged basmati rice (Oryza sativa L.). Natulae botanicae horti agrobotanici cluj-napoca, 42(2): 372-379.

MAFF, 1984. Energy allowances and feeding systems for ruminants. Her Majesty's Stationary Office London, UK.
Naik, D.S., Chetti, M.B. 2017. Influence of packaging and storage conditions on proximate composition of paddy. Int. J. Pure App. Biosci., 5(6): 1632-1639.

Pinkerton, B. 2005. Forage Quality. Clemson University Cooperative Extension Service. Forage fact sheet 2.

Sahu, B., Khokhar, B., Patel, S., Mishra, N.K., Dahare, R. 2018. Comparative analysis on chemical properties of selected varieties of paddy. Int. J. Pure App. Biosci., 6(2): 1352-1357.

Sezer, i. 1993. Çeltiğin verim, Verim Unsurları ile Bazı Kalite Karakterlerine Ekim Yöntemi ve Bitki Sıklığının Etkileri Üzerine Bir Araştırma. Doktora Tezi. O.M.Ü. Fen Bil. Ens. Samsun, 131 s.

SPSS, 1999. Statistical Package for the Social Sciences for Windows, 1999. SPSS Inc., Chicago, Illinois, USA.

Şavşatlı, Y., Gülümser A. 2006. Fideleme ve serpme ekim yöntemlerinin bazı çeltik çeşitlerinde verim ve kalite karakterlerine etkileri. OMÜ Zir. Fak. Dergisi, 21(2):154-159.

Toksal, A. 1991. Çarşamba Ovasında Bazı Çeltik (Oryza sativa L.) Çeşitlerinin Verim, Verim Öğeleri ve Tane Kalitesi Üzerine Bir Araştırma. Yüksek Lisans Tezi, Ondokuz Mayıs Üniversitesi, Fen Bilimleri Enstitüsü, Samsun.

Trakya Tarımsal Araştırma Enstitüsü Müdürlüğü, $2018 . \quad$ Çeltik çeşitleri. https://arastirma.tarim.gov.tr/ttae/Link/1/Ces itlerimiz.

TUiK, 2017. Türkiye İstatistik Kurumu Verileri.

Weiss, W.P., Conrad, H.R., St Pierre, N.R. 1992. A theoretically-based model for predicting total digestible, nutrient values of forages and concentrates. Animal Feed Science and Technology, 39(1-2): 95-110.

Van Soest, P.J., Robertson, J.D., Lewis, B.A. 1991. Methods for dietary fibre, neutral detergent fibre and non-starch polysaccharides in relation to animal Nutrition. Journal of Dairy Sci., 74: 3583-3597.

Yılmaz, N., Sonkaya, M.C. 2018. Çinko uygulamasının çeltik (Oryza sativa L.) çeşitlerinde bazı kalite özellikleri üzerine etkisi. Akademik Ziraat Dergisi, 7(1): 35-40. 